Glass, A. J., A. J. Caven, D. Kim, M. O. Sutton, and N. Arcilla. 2020. Climate change and land management implications for a declining Neotropical migratory songbird breeding in the North American Great Plains. Avian Conservation and Ecology 15(1):4. https://doi.org/10.5751/ ACE-01515-150104

Copyright (C) 2020 by the author(s). Published here under license by the Resilience Alliance.

Research Paper

\title{
Climate change and land management implications for a declining Neotropical migratory songbird breeding in the North American Great Plains
}

\author{
Alex J. Glass ${ }^{1,2}$, Andrew J. Caven ${ }^{2}$, Daniel Kim ${ }^{2,3}$, Madison O. Sutton ${ }^{2,4}$ and Nico Arcilla ${ }^{2,5,6}$ \\ ${ }^{1}$ Cooperative Wildlife Research Laboratory, Southern Illinois University, Carbondale, IL USA, ${ }^{2}$ The Crane Trust, Wood River, NE \\ USA, ${ }^{3}$ USFWS Ecological Services, Pierre, SD USA, ${ }^{4}$ Department of Biological Sciences, Marquette University, Milwaukee, WI \\ USA, ${ }^{5}$ International Bird Conservation Partnership, Huddinge, Sweden, ${ }^{6}$ Center for Great Plains Studies, University of Nebraska, \\ Lincoln, NE USA
}

\begin{abstract}
Anthropogenic climate change and habitat loss pose major threats to grassland breeding birds, the most rapidly declining group of birds in continental North America. Although previous studies have investigated grassland breeding bird responses to land management, few empirical studies explore their responses to climatic variation or its interactions with land management, which warrant urgent conservation attention. We evaluated the effects of climate and land management parameters on an indicator species for grassland breeding birds, the Grasshopper Sparrow (Ammodramus savannarum), a Neotropical migrant of conservation concern whose global population has declined by more than two thirds since 1970. We quantified Grasshopper Sparrow responses to climate variation, land management actions, and their interactions in the Platte River Valley, Nebraska, in the North American Great Plains, using six years of mark-recapture data collected via the Monitoring Avian Productivity and Survivorship (MAPS) protocol. We implemented generalized linear mixed models to estimate avian population trends (adult abundance and productivity) in response to changes in precipitation and temperature as well as cattle grazing, haying, and prescribed burning. Our models showed that climatic variation, especially spring precipitation, was the most important driver of avian population trends. Grasshopper Sparrow abundance declined with increasing spring precipitation, but prescribed burns helped mitigate this effect and were positively related to productivity, especially during years of lower spring temperatures. Our findings demonstrate the vulnerability of grassland bird population trends to ongoing and predicted climate change as well as the potential of land management actions to mitigate some negative effects of climate change on grassland breeding birds.
\end{abstract}

\section{Conséquences du changement climatique et de la gestion des terres sur un passereau migrateur néotropical en diminution dans les Grandes Plaines d'Amérique du Nord}

RÉSUMÉ. Les changements climatiques d'origine anthropique et la perte d'habitat constituent des menaces majeures pour les oiseaux de prairie nicheurs, groupe d'espèces qui diminue le plus rapidement en Amérique du Nord continentale. Bien que des études antérieures aient examiné les réactions des oiseaux de prairie nicheurs suivant la gestion des terres, peu d'études empiriques ont exploré leurs comportements à la suite de variations climatiques ou leurs interactions avec l'aménagement des terres, qui méritent pourtant une attention urgente pour la conservation. Nous avons évalué les effets du climat et des paramètres de gestion des terres sur une espèce représentative des oiseaux de prairie nicheurs, le Bruant sauterelle (Ammodramus savannarum), un migrateur néotropical dont la population mondiale a diminué de plus des deux tiers depuis 1970. Nous avons quantifié les réactions des Bruants sauterelles aux variations climatiques, aux mesures de gestion des terres et à leurs interactions dans la vallée de la rivière Platte, au Nebraska, dans les Grandes Plaines d'Amérique du Nord, en utilisant six ans de données de marquage-recapture collectées au moyen du protocole MAPS (Monitoring Avian Productivity and Survivorship). Nous avons conçu des modèles linéaires généralisés à effets mixtes pour estimer la démographie (abondance des adultes et productivité, ou nombre de jeunes) en réponse aux changements de précipitation et de température ainsi qu'au pâturage du bétail, à la fenaison et au brûlage dirigé. Nos modèles montrent que la variation climatique, en particulier les précipitations printanières, était le facteur principal agissant sur les tendances démographiques. Le nombre de Bruants sauterelles a diminué avec l'augmentation des précipitations printanières, mais les brûlages dirigés ont aidé à atténuer cet effet et étaient positivement liés à la productivité, surtout lors des années de températures printanières plus basses. Selon nos résultats, les populations d'oiseaux de prairie sont vulnérables aux changements climatiques en cours et prévus, et des mesures de gestion des terres adéquates peuvent atténuer certains effets négatifs des changements climatiques sur les oiseaux de prairie nicheurs.

Key Words: Ammodramus savannarum; avian demography; climate; conservation; Grasshopper Sparrow; grassland breeding birds; management; Monitoring Avian Productivity and Survivorship 


\section{INTRODUCTION}

Anthropogenic climate change is affecting biodiversity worldwide, including over half of North American bird species, and its effects are expected to intensify in the coming years (Foden et al. 2013, Langham et al. 2015). Under current climate change predictions, North American breeding birds will encounter increasingly novel climates characterized by large seasonal and spatial climate variation that may pose serious threats to their populations (La Sorte et al. 2019). At the same time, agricultural expansion and intensification (Rickletts et al. 1999, Samson et al. 2004) has been driving worldwide declines in habitat and terrestrial biodiversity (Millennium Ecosystem Assessment 2005, Butchart et al. 2010). One of the world's largest temperate grassland ecosystems, the Great Plains has incurred more habitat loss and hydrological change than any other North American ecosystem because of agricultural expansion and intensification (Sohl et al. 2019). Consequently, birds breeding in the Great Plains have suffered the steepest declines of any region on the continent (Rosenberg et al. 2016, NABCI 2017). Ongoing climate change is expected to cause further declines in Great Plains breeding birds by driving range contractions and shifts (Gorzo et al. 2016). However, few empirical studies in the Great Plains have assessed breeding bird responses to climatic variation or their interactions with habitat management, limiting our ability to deal with these threats through adaptive management and conservation planning.

Great Plains grasslands are disturbance-dependent ecosystems that were historically shaped by seasonal flooding, wildfires, and ecosystem engineers such as American bison (Bison bison) and black-tailed prairie dogs (Cynomys ludovicianus; Currier 1982, Collins 1990, Anderson 2006). These natural disturbances have been virtually eliminated since the European colonization of the Great Plains and subsequent extirpation of bison, prairie dogs, and other ecosystem engineers from most of their native range as well as the damming of rivers and suppression of wildfires. Today, land management practices such as prescribed burning, cattle grazing, and haying may partially mimic the natural disturbances of the past (Gibson and Hulbert 1987, Briggs and Knapp 1995, Briggs et al. 2005). Such disturbances maintain habitat for a wide variety of grassland breeding birds and other taxa by creating heterogeneity in grassland structure, species composition, and successional state (Thogmartin et al. 2006, Fuhlendorf et al. 2006, 2009). Grassland structure and composition are critical components of breeding bird habitat quality, and may vary dramatically from year to year depending on land management actions and climatic variation (Patterson and Best 1996, Fuhlendorf and Engle 2004, Winter et al. 2005, Coppedge et al. 2008, Gorzo et al. 2016).

Grassland breeding bird species have evolved to specialize in particular ecological niches within disturbance gradients, such that land management practices have significant consequences for their breeding success (e.g., Delaney et al. 2002, Reinking 2005, Sutter and Ritchison 2005, Coppedge et al. 2008, Rahmig et al. 2009). Henslow's Sparrows (Centronyx henslowii), for example, tend to nest in mature tallgrass prairies three or more years postdisturbance, e.g., grazing, haying, burning, which harbor significant levels of nesting material (Herkert 1998, Thogmartin et al. 2006, Fuhlendorf et al. 2009). Upland Sandpipers (Bartramia longicauda), by contrast, tend to forage and nest in grasslands with more recent disturbances (Dechant et al. 2002, Thogmartin et al. 2006, Fuhlendorf et al. 2009). Studying grassland birds' responses to land management enables sciencebased conservation efforts, but few empirical studies have examined the role that climatic factors, e.g., precipitation or temperature, play in moderating, mitigating, or enhancing the intended effects of land management actions on birds (Jones et al. 2007, Yarnell et al. 2007, Archibald 2008, Kim et al. 2008).

Ongoing anthropogenic climate change is predicted to strongly affect temperature and precipitation levels in the Great Plains, now and in the future (Ojima et al. 2012, Gorzo et al. 2016). Grassland bird populations as a group have exhibited $>50 \%$ declines in abundance since 1970 (Rosenberg et al. 2019), and effective conservation planning will require information about avian responses to climatic variation as well as land management. Here, we examine the effects of climate and land management variables on the Grasshopper Sparrow (Ammodramus savannarum), an indicator species whose densities are effective predictors of the densities of many other grassland breeding bird species, such as Eastern and Western Meadowlarks (Sturnella magna, S. neglecta), Bobolinks (Dolichonyx oryzivorus), Henslow's Sparrows, and Dickcissels (Spiza americana; Thogmartin et al. 2006, Rosenberg et al. 2016, Elliot and Johnston 2018). A Neotropical migrant whose wintering range extends from southern United States and Mexico to Central America and the Caribbean, the Grasshopper Sparrow has an extensive breeding range in North America, but is uncommon to rare in many parts of its range (Vickery 1996). Its global population has fallen by nearly $70 \%$ since 1970 , leading to its designation as a species of conservation concern by the U.S. Fish and Wildlife Service (Ruth 2015, Rosenberg et al. 2016). Grasshopper Sparrow breeding abundance peaks in the central Great Plains (Sauer et al. 2014), but its Nebraska population has been declining nearly $2 \%$ annually (Silcock and Jorgensen 2018) as grasslands continue to be converted to monoculture crops.

Grasshopper Sparrows forage exclusively on the ground, hunting grasshoppers, other arthropods, and seeds (Martin et al. 1951, Vickery et al. 1999). To maximize their foraging success during the breeding season, they tend to select relatively dry, sparsely vegetated sites in tallgrass prairies with patchy bare ground (Delaney et al. 1985, Vickery et al. 1999), which tend to be associated with frequent disturbance (Vickery 1996, Balent and Norment 2003, Ruth 2015). Studies in other systems have found correlations between Grasshopper Sparrow abundance and frequent burning and grazing (Swengel and Swengel 2001, Guiliano and Daves 2002, Sutter and Ritchison 2005, Fuhlendorf et al. 2006), with abundance peaking around one to two years after burning (Fuhlendorf et al. 2006, Powell 2006, 2008). Grasshopper Sparrows construct highly cryptic nests that typically feature overhanging grasses and a side entrance (Vickery et al. 1999, Fogarty et al. 2017), camouflage that provides some protection against predators, and brood parasitism by Brownheaded Cowbirds (Molothrus ater; Vickery et al. 1999).

Here, we assess breeding Grasshopper Sparrow population responses to climatic variation and land management in tallgrass prairie in the Platte River Valley in the central Great Plains. Our main objective was to elucidate their vulnerability to ongoing and future climate change and to investigate the ability of targeted 
Fig. 1. Map of Grasshopper Sparrow sampling locations in the central Platte River Valley, Nebraska Great Plains.

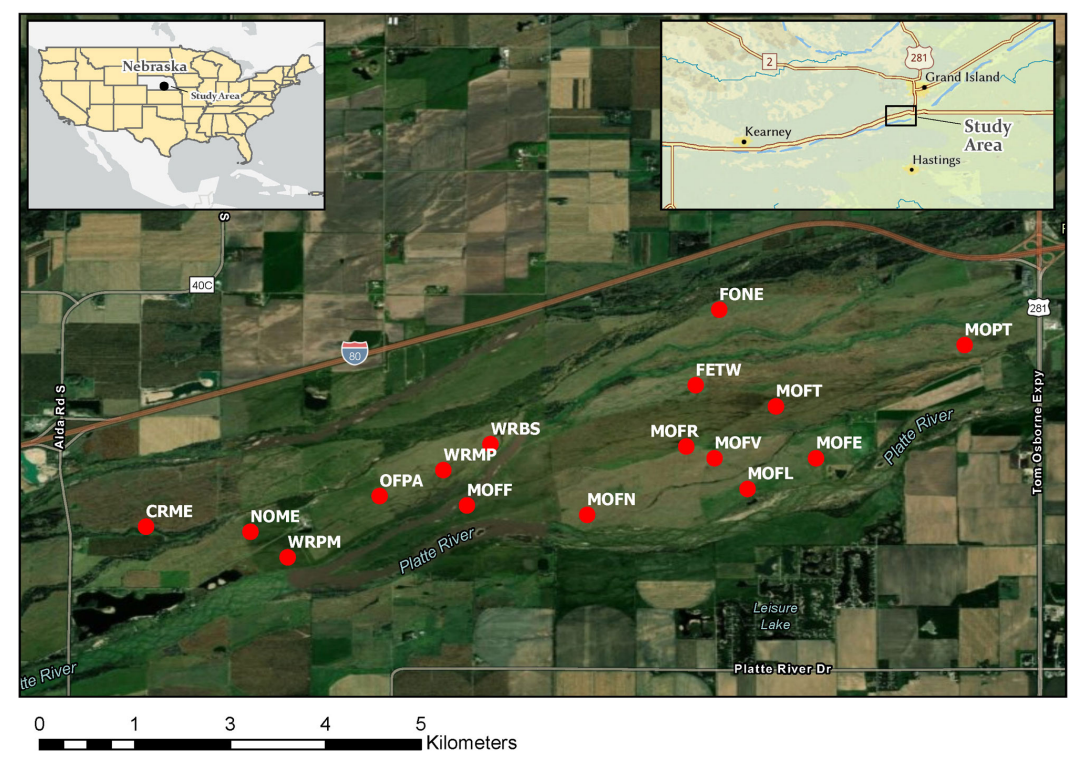

land management to mitigate those impacts. We hypothesized that climatic variation would strongly influence Grasshopper Sparrow abundance, because changes in precipitation and temperature affect soil moisture and vegetation growth that are critical to successful foraging and breeding (Rahmig et al. 2009, Ahlering and Merkord 2016). Specifically, we predicted that higher temperatures would be associated with bird declines (Gorzo et al. 2016) in association with decreased food availability and increased physiological stress on birds, and that higher precipitation levels would be correlated with declining population trends (Kim et al. 2008) in association with flooding and plant growth in excess of ideal foraging or breeding conditions for this species. We further hypothesized that managed disturbances, which regulate biomass production and vegetative structure, could magnify or mitigate the impacts of climatic variation on bird abundance and productivity (Fuhlendorf and Engle 2004, Thogmartin et al. 2006, Kim et al. 2008).

\section{METHODS}

\section{Study system}

We investigated Grasshopper Sparrow abundance and productivity on $\sim 2025$ ha of lowland tallgrass prairie in the central Platte River Valley, Nebraska (40.798 ${ }^{\circ} \mathrm{N},-98.416^{\circ} \mathrm{W}, \sim 600 \mathrm{~m}$ asl). A globally recognized Important Bird Area (Poague 2019), the central Platte River Valley features riparian wet meadows and lowland tallgrass prairies that provide breeding and stopover habitat for a high diversity of birds, particularly migratory waterbird and grassland breeding species (Lingle and Hay 1982, Sharpe et al. 2001, Kim 2005, Johnsgard and Brown 2013). A remnant of the critically endangered North American Central and Southern Mixed Grasslands ecoregion, where $95 \%$ of native habitat has been converted to agriculture and other human uses, this landscape harbors the highest floristic diversity of any North American grassland (Barbour et al. 1980). The Platte River extends the westward reach of eastern tallgrass prairie habitat by raising the water table and increasing available subsurface moisture for the long roots of perennial prairie grasses (Currier 1982, Kaul and Rolfsmeier 1993, Kaul et al. 2006). Habitat in this region was historically structured by disturbances caused by Plains bison (Bison bison bison), wildfires, and seasonal floods that prevented woody encroachment and maintained early successional vegetation (Williams 1978, Anderson 2006). European colonization in the late 19th century fundamentally altered wildlife in this region by causing extinctions, extirpations, and population reductions of many native species and subspecies such as the Eskimo Curlew (Numenius borealis), Great Plains wolf (Canis lupus nubilus), American bison, black-tailed prairie dog, and Greater Prairie-Chicken (Tympanuchus cupido). Many nonnative species were subsequently introduced, both accidentally and deliberately, including cattle, exotic grasses, and other plants and animals that have major impacts on surviving native species (Willson and Stubbendieck 2000). Seasonal flood pulses were also substantially reduced through extensive damming of the Platte River (Currier 1982, Junk et al. 1989).

\section{Study design}

We carried out fieldwork on two adjacent river islands, Mormon and Shoemaker islands, which constitute the largest contiguous expanse of prairie habitat remaining in the central Platte River Valley (Krapu et al. 2014). Land management practices in our study area included rotational cattle grazing (resting every three to four years), and haying (every two to four years), and patch burning (every two to six years). During our sampling period, burning took place in the spring prior to the bird breeding season, while grazing periods often overlapped with the breeding season. Haying occurred after the breeding season in the late summer or fall. We sampled birds at a total of 16 grassland sites (Fig. 1), of which three sites were sampled for six consecutive years, while 13 were sampled for periods between one to five years. Of the 16 total sites, 10 were grazed, four were hayed, and two were neither 
Table 1. Grasshopper Sparrow (Ammodramus savannarum) sampling locations (Monitoring Avian Productivity and Survivorship [MAPS] stations) in the central Platte River Valley, Nebraska Great Plains: site names and characteristics 2002-2007.

\begin{tabular}{lllll}
\hline \hline Site & $\begin{array}{l}\text { Size } \\
\text { (ha) }\end{array}$ & Years MAPS stations were active & $\begin{array}{l}\text { Grazed/ } \\
\text { Hayed }\end{array}$ & Burned \\
\hline CRME & 117 & 2003,2004 & Neither & Spring 2004 \\
FETW & 104 & $2005,2006,2007$ & Grazed & Spring 2005 \\
FONE & 130 & $2003,2004,2005,2006,2007$ & Grazed & Spring 2001, Spring 2005 \\
MOFE & 118 & $2002,2003,2004,2005,2006,2007$ & Hayed & Spring 2000, Spring 2006 \\
MOFF & 94 & $2002,2004,2005,2006,2007$ & Grazed & Spring 2001, Spring 2006 \\
MOFL & 118 & 2003 & Hayed & Spring 2000 \\
MOFN & 118 & $2002,2004,2005,2006,2007$ & Grazed & Spring 2003, Spring 2007 \\
MOFR & 104 & $2003,2006,2007$ & Grazed & Spring 2002, Spring 2004 \\
MOFT & 130 & $2002,2003,2004,2005,2006,2007$ & Grazed & Spring 2004, Spring 2007 \\
MOFV & 103 & $2002,2005,2006$ & Hayed & Spring 1996 \\
MOPT & 103 & $2005,2006,2007$ & Grazed & Spring 2005 \\
NOME & 55 & $2003,2004,2005,2006,2007$ & Hayed & Spring 2000, Spring 2004, Spring 2007 \\
OFPA & 49 & $2003,2004,2007$ & Grazed & Fall 1998, Spring 2007 \\
WRBS & 29 & $2002,2003,2004,2006$ & Grazed & Spring 2002, Spring 2003 \\
WRMP & 33 & 2005 & Grazed & Spring 2002 \\
WRPM & 14 & $2002,2003,2004,2005,2006,2007$ & Neither & Spring 2000, Spring 2007 \\
\hline
\end{tabular}

grazed nor hayed. All of the sites were burned at least once during the years in which the data were collected (Table 1). Sites (hereafter pastures) ranged in size from 14 to $130 \mathrm{ha}$ (mean $=88.7 \mathrm{ha}$, median $=103.5 \mathrm{ha}$ ), and were delineated by physical barriers including fencing, sloughs, river channels, and roads.

\section{Bird sampling}

We analyzed mark-recapture data collected annually from May 2002 to August 2007, using methods standardized by the Monitoring Avian Productivity and Survivorship (MAPS) program (DeSante and Kaschube 2009, DeSante et al. 2017) under U.S. federal bird banding permit 23224. Twelve mist nets $(12 \times 3 \mathrm{~m}, 30 \mathrm{~mm}$ mesh) were set up in each pasture in areas ranging in size from $180 \times 200 \mathrm{~m}$ to $450 \times 480 \mathrm{~m}($ mean $=287 \times 323 \mathrm{~m})$. In accordance with MAPS protocols, each sampling occasion consisted of a netting period of six hours following sunrise ( 0600) approximately once every 10 days. Effort was consistent for each sampling occasion and across years. Starting in 2005, most pastures were netted in a $300 \times 300 \mathrm{~m}$ grid, with three rows of four nets. We identified birds captured and fitted each with a uniquely numbered USGS aluminum band, and recorded sex, age, and biometric measurements before releasing them on site (Pyle 1997).

\section{Quantifying climate and land management parameters}

We considered both climate and management parameters as independent variables (Table 1). We generated climate parameters using temperature and precipitation measurements from the National Oceanic and Atmospheric Administration (NOAA 2017) online database for the city of Grand Island, Nebraska (located approximately $20 \mathrm{~km}$ northeast of our research site). We created four variables to estimate yearly climatic variation: average temperature and total precipitation for the spring (MarchMay) of the current year, and average temperature and total precipitation for the previous year (January-December).
To investigate the effects of management actions, we created three management variables that represented time (months) since disturbances (grazing, haying, and burning) at sampling sites. For this analysis, we capped months since disturbance at 240 months (20 years), because management actions that occurred earlier than this were unlikely to have any predictable effect on habitat structure (Collins 2000). To investigate the effects of management intensity in the case of grazing, we created two additional management variables that quantified grazing via the cattle stocking rate on grazed pastures. We measured stocking rate in animal unit months per hectare (AUM/ha), which is defined as the forage requirement for one animal unit (mature cow and calf pair) for a 1-month period (Hamilton 2007, Johnson et al. 2011). Our first stocking rate variable quantified AUM/ha at each study site at the time of data collection (hereafter referred to as current stocking rate). Our second variable represented the average AUM/ ha at each site for the sampling year plus the four years preceding data collection, i.e., grazing history. Sites that were not grazed during MAPS data sampling were given a value of 0 .

\section{Statistical analysis}

We analyzed Grasshopper Sparrow capture data across all 16 sites using R Studio version 3.4.0 (R Core Team 2017). We removed recaptures of individuals that occurred during the same year and at the same site from the dataset to avoid double-counting. Pastures in this study were often grazed for the first or second half of the summer, meaning that the values of variables such as months since grazing and current stocking rate could change for a single pasture within a banding season. To address this issue, each banding season was separated into two sampling periods for analysis, which broadly correspond to the first and second halves of the bird breeding season. The first sampling period covered MAPS periods 3-6, roughly the end of May until the beginning of July, and the second covered MAPS periods $7-10$, or the beginning of July until the beginning of August. We quantified two different response variables: (1) the number of unique adult Grasshopper Sparrows captured, an index of abundance 
Table 2. Individual Grasshopper Sparrow (Ammodramus savannarum) adult $(\mathrm{n}=982)$ and juvenile $($ Hatch-Year; $\mathrm{n}=463)$ birds captured and released at each sampling location 2002-2007.

\begin{tabular}{|c|c|c|c|c|c|c|c|c|c|c|c|c|c|c|}
\hline \multirow[b]{2}{*}{ Site } & \multicolumn{7}{|c|}{ Adults } & \multicolumn{7}{|c|}{ Hatch-years } \\
\hline & 2002 & 2003 & 2004 & 2005 & 2006 & 2007 & Total & 2002 & 2003 & 2004 & 2005 & 2006 & 2007 & Total \\
\hline CRME & & 2 & 4 & & & & 6 & & & 1 & & & & 1 \\
\hline FETW & & & & 13 & 13 & 5 & 31 & & & & 3 & 3 & 6 & 12 \\
\hline FONE & & 35 & 28 & 28 & 36 & 23 & 150 & & 48 & 20 & 20 & 14 & 34 & 136 \\
\hline MOFE & 24 & 12 & 6 & 1 & 3 & 4 & 50 & 19 & 2 & 0 & 0 & 5 & 0 & 26 \\
\hline MOFF & 22 & & 10 & 3 & 17 & 2 & 54 & 28 & & 3 & 0 & 6 & 1 & 38 \\
\hline MOFL & & 38 & & & & & 38 & & 17 & & & & & 17 \\
\hline MOFN & 14 & & 38 & 19 & 28 & 7 & 106 & 5 & & 14 & 17 & 3 & 9 & 48 \\
\hline MOFR & & 5 & & & 5 & 1 & 11 & & 1 & & 1 & 1 & 0 & 3 \\
\hline MOFT & 3 & 5 & 9 & 17 & 29 & 23 & 86 & 0 & 0 & 3 & 6 & 1 & 10 & 20 \\
\hline MOFV & 5 & & & 27 & 35 & & 67 & 1 & & & 4 & 4 & & 9 \\
\hline MOPT & & & & 16 & 34 & 15 & 65 & & & & 4 & 13 & 0 & 17 \\
\hline NOME & & 18 & 19 & 7 & 16 & 5 & 65 & & 10 & 11 & 1 & 4 & 11 & 37 \\
\hline OFPA & & 27 & 24 & & & 29 & 80 & & 3 & 12 & & & 4 & 19 \\
\hline WRBS & 11 & 19 & 17 & & 46 & & 93 & 33 & 12 & 3 & & 14 & & 62 \\
\hline WRMP & & & & 5 & & & 5 & & & & 1 & & & 1 \\
\hline WRPM & 11 & 14 & 7 & 11 & 18 & 14 & 75 & 4 & 2 & 2 & 1 & 3 & 5 & 17 \\
\hline Total & 90 & 175 & 162 & 147 & 280 & 128 & 982 & 90 & 95 & 69 & 58 & 71 & 80 & 463 \\
\hline
\end{tabular}

(hereafter, abundance); and (2) the probability of a captured bird being a hatch-year bird, an index of productivity (hereafter, productivity; Foster et al. 2017, Saracco et al. 2019).

Before constructing candidate models, we tested for correlations among independent variables. Variables that were highly correlated $(r>0.6)$ were not included in the same model. We created a series of candidate models as generalized linear mixed models in the R package glmmTMB (Brooks et al. 2017). We employed a negative binomial distribution for the abundance models to account for overdispersion of our count data (O'Hara and Kotze 2010), and used a binomial distribution for productivity models. We created model sets consisting of management variables, and additive and/or interactive combinations of management and climate variables we developed a priori. For the productivity model set, we used the values of management variables from period 1 only, because this corresponds with the time that most birds are nesting. We included site in all models as a random effect to account for variations among sites not otherwise accounted for in our models. Variables were scaled and centered before fitting them to models, by subtracting the mean of each variable and dividing the result by the variable's standard deviation (Bring 1994). Our null model included site as a random effect, but no management or climate variables.

We used Akaike's Information Criterion (Akaike 1973) adjusted for small sample size ( $\mathrm{AIC}_{c}$; Hurvich and Tsai 1989) to assess the fit of each model, which was determined by evaluating $\mathrm{AIC}_{c}$ values and Akaike weights $\left(w_{i}\right)$ in the R package MuMIn (Bartoń 2019). We created a confidence set of models with a $\Delta \mathrm{AIC}_{c}<2$ of the best fitting model (Burnham and Anderson 2002). We assessed the relative importance of predictor variables by measuring the cumulative $\mathrm{AIC}_{c}$ weights of models containing the variable, and by comparing model-averaged standardized regression coefficients $(\beta)$ and their $95 \%$ confidence intervals.

\section{RESULTS}

We analyzed data from 1445 Grasshopper Sparrows (Table 2), including 982 adults and 463 juveniles. We captured 1040 birds on grazed pastures (mean per pasture $=104.0 \pm 25.9 \mathrm{SE}, n=10$ pastures), 306 on hayed pastures (mean $=76.5 \pm 9.0 \mathrm{SE}, n=4$ pastures), and 99 on pastures that were not grazed or hayed (mean $=49.5 \pm 60.1 \mathrm{SE}, n=2$ ). The number of Grasshopper Sparrows captured per year varied between 180 in 2002 and 351 in 2006 $($ mean $=242.5 \pm 25.7 \mathrm{SE})$. Climate parameters (precipitation and temperature) had the greatest effects on Grasshopper Sparrow population responses. Spring precipitation was the strongest predictor of avian abundance, and the interaction of spring temperature and months since burning was the strongest predictor of avian productivity. We found no evidence of year affecting the number of captures, beyond the yearly variations in climate already accounted for in our models. Similarly, we found no association between abundance in grazed versus hayed pastures. Adding year or pasture type (grazed versus hayed) as predictor variables to our models decreased their $\Delta \mathrm{AIC}_{c}$ by at least 2 , indicating that they had little effect on abundance (Burnham and Anderson 2002). Thus, we did not include variables representing year or management type in the final model set.

\section{Abundance}

Our top models predicting adult Grasshopper Sparrow abundance all included spring precipitation $\left(\Delta \mathrm{AIC}_{c}<2, n=3\right.$, Table 3). The highest-ranked model was spring precipitation alone $\left(w_{i}=0.283\right)$. Our second-ranked model included the interaction of spring precipitation with months since haying $\left(\Delta \mathrm{AIC}_{c}=1.55\right)$. Our third-ranked model included the interaction of spring precipitation and grazing history $\left(\Delta \mathrm{AIC}_{c}=1.98\right)$. Although both spring climatic and management variables were present in our strongest abundance models (Table 3), climatic variables representing the previous year were absent. Spring precipitation $(\beta=-0.034$, C.I. $=-0.055,-0.009$, Table 4$)$ had a negative impact on adult abundance. 
Table 3. AIC ranking of top candidate models (of 24 total) that predict Grasshopper Sparrow (Ammodramus savannarum) abundance (top 4 models plus null model) and productivity (top 3 models plus null model) in response to climate and land management variables and their interactions.

\begin{tabular}{|c|c|c|c|c|}
\hline $\begin{array}{l}\text { Response variable } \\
\text { Model }^{\dagger}\end{array}$ & $\mathrm{K}^{*}$ & $\mathrm{AIC}^{\S}$ & $\Delta \mathrm{AIC}^{\mathrm{l}}$ & $w_{i}^{\pi}$ \\
\hline \multicolumn{5}{|l|}{ Abundance } \\
\hline precip.spring & 4 & 751.59 & 0 & 0.283 \\
\hline hay.months $\mathrm{x}$ precip.spring & 6 & 753.14 & 1.545 & 0.131 \\
\hline grazing.history $\mathrm{x}$ precip.spring & 6 & 753.58 & 1.983 & 0.105 \\
\hline $\begin{array}{l}\text { temp.spring }+ \text { precip.spring }+ \text { current. } \\
\text { stocking.rate }\end{array}$ & 6 & 753.73 & 2.134 & 0.097 \\
\hline null & 3 & 757.24 & 5.648 & 0.017 \\
\hline \multicolumn{5}{|l|}{ Productivity } \\
\hline burn.months $\mathrm{x}$ temp.spring & 5 & 1723.67 & 0 & 0.918 \\
\hline temp.spring $\mathrm{x}$ precip.spring & 5 & 1728.53 & 4.859 & 0.081 \\
\hline temp.year x precip.year & 5 & 1737.51 & 13.831 & 0.001 \\
\hline null & 2 & 1763.79 & 40.119 & 0 \\
\hline \multicolumn{5}{|c|}{ 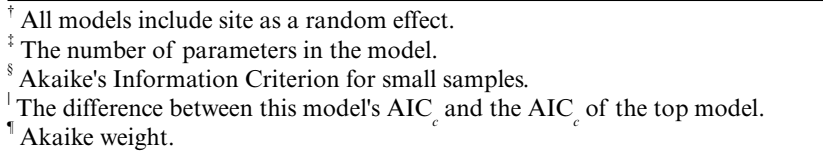 } \\
\hline
\end{tabular}

Table 4. Model-averaged climate and land management parameter estimates within $2 \Delta \mathrm{AIC}$ of top model.

\begin{tabular}{lccc}
\hline \hline Parameter & Estimate & $\begin{array}{c}95 \% \text { confidence } \\
\text { intervals }\end{array}$ & $\begin{array}{c}\text { Cumulative } \\
\text { model } \\
\text { weight }\end{array}$ \\
\hline Abundance & & & \\
precip.spring & -0.03375 & -0.055 to -0.009 & 0.822 \\
hay.months & -0.0267 & -0.077 to 0.03 & 0.142 \\
grazing.history & 0.02875 & -0.011 to 0.069 & 0.138 \\
hay.months x precip.spring & 0.01431 & -0.008 to 0.037 & 0.131 \\
grazing.history x precip.spring & 0.00854 & -0.012 to 0.029 & 0.105 \\
& & & \\
Productivity & & & 0.999 \\
temp.spring & -0.4865 & -0.771 to -0.178 & 0.918 \\
burn.months & -0.8178 & -1.176 to -0.459 & 0.918 \\
burn.months x temp.spring & 0.40451 & 0.087 to 0.721 & 0 \\
\hline
\end{tabular}

\section{Productivity}

The interaction of time since burning and spring temperature was the strongest predictor of avian productivity $\left(w_{i}=0.918\right.$, Table 3). No other model was within $2 \Delta \mathrm{AIC}_{c}$, making this by far the most competitive model in our model set. Grasshopper Sparrow productivity was negatively related to months since burning ( $\beta$ $=-0.818$, C.I. $=-1.176,-0.459$ ), meaning that productivity was highest in recently burned areas. The effect size of months since burning on productivity decreased with increasing spring temperature (Fig. 2).

\section{DISCUSSION}

Our results demonstrate the vulnerability of Grasshopper Sparrows (and by extension, other grassland breeding birds) to ongoing and future climate change, and indicate the potential of particular land management strategies to mitigate some of the negative impacts of climate change. Both spring precipitation and temperature levels had significant effects on Grasshopper Sparrow population trends. Spring precipitation, the strongest predictor of adult Grasshopper Sparrow abundance (Table 2), was negatively related to adult bird abundance but did not have a measurable effect on productivity. By contrast, productivity was higher in sites that had been recently burned, and this trend was more pronounced after cooler springs (Fig. 2). Although both abundance and productivity responded positively to moderate disturbance caused by management actions, increased temperatures lessened this effect for productivity but had no effect on abundance. The existence of different drivers of abundance and productivity raises the possibility that a particular set of conditions could drive these demographic variables in different directions, setting the stage to create either population sources or sinks that function as ecological traps (Schlaepfer et al. 2002, Foster et al. 2017).

Fig. 2. Grasshopper Sparrow productivity and 95\% confidence intervals in response to grassland regeneration time (months) since burning, based on linear regression of mark-recapture data on number of individual juveniles captured per day $(n=$ 463); Productivity during years of above-average spring temperature and below-average spring temperature from 2002-2007 are plotted separately.

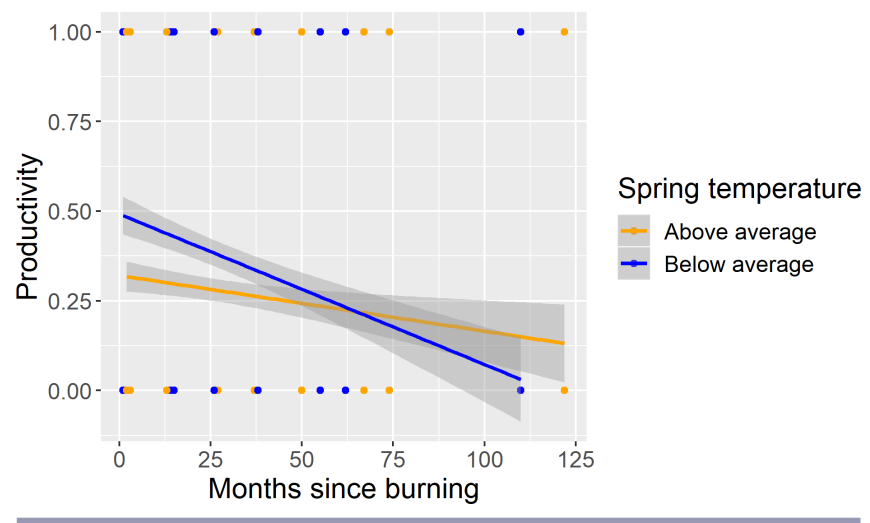

\section{Abundance}

Although identifying the mechanisms driving these patterns are beyond the scope of this research, we can use the results to hypothesize what they might be. We hypothesize that increasing spring precipitation was related to decreasing bird abundance because higher spring precipitation is conducive to plant growth in excess of ideal conditions for this species, which tends to avoid tall and dense vegetation (Patterson and Best 1996). Spring precipitation has a strong influence on bird breeding season vegetation structure, an important factor for habitat selection for Grasshopper Sparrows and other grassland birds (George et al. 1992, Fletcher and Koford 2002, Winter et al. 2005). Even small changes in spring precipitation have an important effect on vegetation structure and biomass production in tallgrass prairie (Coppedge et al. 1998), and generally interact with management activities (Rahmig et al. 2009, Ahlering and Merkord 2016). Several other studies (Derner and Hart 2007, Augustine and Milchunas 2009) have documented the effects of spring precipitation on vegetation structure and biomass production in other North American grassland ecosystems. Grasshopper 
Sparrows' foraging success depends in part on the presence of sparse grassland with patchy bare ground, allowing them optimal access to their arthropod prey (Vickery et al. 1999).

The negative effect of spring precipitation on Grasshopper Sparrow abundance is consistent with findings by Kim et al. (2008) in the same study system that showed Grasshopper Sparrow population density in grazed pastures increased with drier conditions (as measured by the Palmer Drought Severity Index of the current year) from 1980 to 1996. Abundance increased along with a site's grazing history in our study. This effect was stronger after wetter springs because the resulting increase in vegetation growth may be associated with decreased overall Grasshopper Sparrow abundance (Fig. 3), but increased the importance of grazing as a tool to maintain vegetation structure at the levels conducive to higher Grasshopper Sparrow abundance. By contrast, a study in the Badlands and Prairies Bird Conservation Region about $560 \mathrm{~km}$ northwest of our study site in dry short-grass prairie, found that Grasshopper Sparrows were negatively affected by drier conditions (Gorzo et al. 2016). Drought conditions may magnify the impact of grazing in creating portions of short vegetation and exposed bare ground (Teague et al. 2004).

Fig. 3. Adult Grasshopper Sparrow abundance and 95\% confidence intervals in response to spring precipitation levels, based on linear regression of mark-recapture data on number of individual adults captured per day $(\mathrm{n}=982)$.

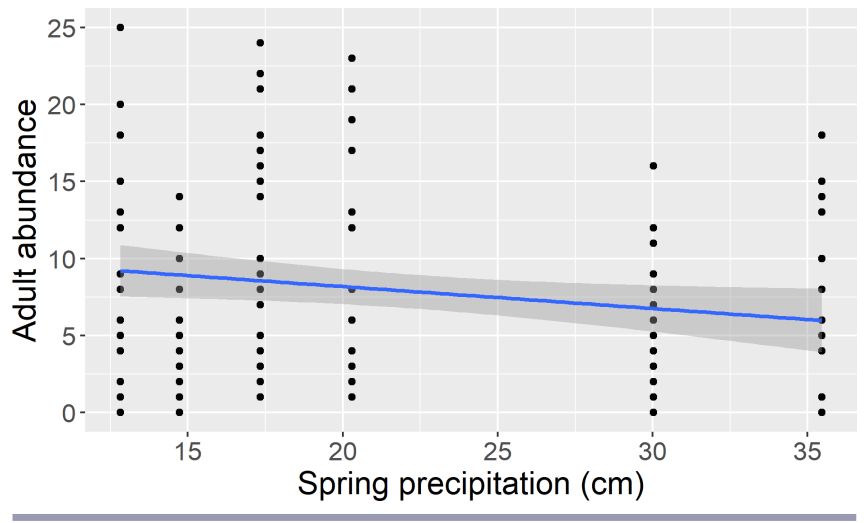

\section{Productivity}

The results of our productivity models were likely influenced to some extent by postfledging movements of young birds to areas with more bare ground and greater foraging potential. Little is known about postfledging dispersal of Grasshopper Sparrows, though a study by Anthony et al. (2013) in Maryland recorded an average dispersal distance of $346 \mathrm{~m}$ for juvenile Grasshopper Sparrows in the first few months after fledging, and concluded that the majority of juveniles remain in their natal area prior to their preformative molt. Our study sites were as close as $300 \mathrm{~m}$ to each other, but often much farther apart (Fig. 1)

Prescribed fire has been previously demonstrated to increase productivity for Grasshopper Sparrows (Rahmig et al. 2009, Hovick et al. 2012, Roberts et al. 2017) and other grassland birds (Roberts et al. 2017). The mechanisms driving this response are understudied; it is possible that recently burned areas promote more successful foraging by decreasing vegetation density and increasing the amount of bare ground that Grasshopper Sparrows depend on for movement during foraging (Vickery et al. 1999, Fletcher and Koford 2002). It is also possible that recent burning increases the density of prey items available. Jonas and Joern (2007) found that the highest densities of grasshoppers in tallgrass prairies in Kansas occurred within one year of a burn. This may contribute to an increased probability of nestling survival, as adults can more effectively feed nestlings, as well as to higher postfledging survival for juveniles learning to forage.

The positive effect of prescribed fire on productivity was more pronounced after cooler springs (Fig. 2). Cooler spring temperatures and recent fire both serve to improve structural habitat characteristics for Grasshopper Sparrows by reducing standing biomass and increasing the amount of bare ground (Gibson and Hulbert 1987, Briggs and Knapp 1995, Coppedge et al. 1998, Fletcher and Koford 2002, Flanagan and Johnson 2005, Flanagan et al. 2013). During seasons with higher temperatures, the benefits provided by more recently burned areas were slightly negated, likely due to the cost of greater physiological stress incurred by nestlings and fledglings in areas with sparser vegetation. With temperatures in this region expected to increase in the future as a result of climate change (Ojima et al. 2012), the positive effect of prescribed fire on grassland bird productivity may become less pronounced. Dense vegetation can provide shelter from high temperatures, which can exceed $38{ }^{\circ} \mathrm{C}$, and associated thermal stress conditions that can lead to nest failure. Greater vegetation cover may contribute to cooler microclimates that aid the nest survival of ground-nesting birds (Carroll et al. 2015, Fogarty et al. 2017). For an adult Grasshopper Sparrow, choosing quality breeding territory may represent a trade-off between recently burned areas with shorter vegetation and bare ground patches that provide greater foraging opportunities, and less-disturbed areas with taller, denser vegetation that can shield nestlings and fledglings from hot summer temperatures and potential predators through visual and olfactory concealment (Fogarty et al. 2017).

\section{CONCLUSION}

Predicted climate change patterns in the Great Plains include more frequent droughts and extreme precipitation events (Touma et al. 2015), which are already underway and will have increasingly important consequences for avian population trends and other biodiversity in the future (Langham et al. 2015). In recent years, precipitation levels in the study area have increased significantly, which may contribute to driving further Grasshopper Sparrow and other bird declines (Rosamond, Goded, Soultan, et al. unpublished manuscript). By contrast, higher rainfall may positively influence this species in drier ecosystems (Gorzo et al. 2016), illustrating how the impacts of climatic variation on avian population trends are often area and ecosystem-dependent. Land management actions to promote increased adult and juvenile Grasshopper Sparrow abundance must consider their respective ecoregions, ecosystems, and environmental conditions. In our case, land management strategies that include frequent burning and moderate grazing appear to maintain vegetation structure for breeding Grasshopper Sparrows (Powell 2008, Fuhlendorf et al. 2009). 
Our findings thus demonstrate the need to incorporate climate factors together with local and regional site characteristics in conservation strategies that consider future climate change scenarios (Gibson and Hulbert 1987, Teague et al. 2004, Rahmig et al. 2009). Our findings also highlight both the potential and the limits of land management actions to locally mitigate negative impacts of climate change on grassland species of conservation concern. In our case, the influence of land management on Grasshopper Sparrow population trends was more constrained in years with low precipitation and high spring temperatures. These constraints highlight an increasing body of evidence that demonstrates the urgent need to make fundamental changes toward reducing the destruction of native grasslands, greenhouse gas emissions, and other factors contributing to species declines and climate change (Ripple et al. 2017).

Positive avian abundance responses may be used to track habitat conditions attractive to breeding birds, whereas habitat quality may be demonstrated by demographic data, such as evidence of breeding success (van Horne 1983, Foster et al. 2017, Saracco et al. 2019). This study focused on drivers of the population dynamics of a species of conservation concern that is also an effective indicator of the densities of other grassland breeding bird species (Elliot and Johnson 2018). Future studies should explore the mechanisms by which climatic variation affects this species and other grassland breeding birds, for example, by specifically investigating food availability and foraging success, thermal stress, and vegetation structure and composition as they affect bird population trends. Such studies would provide additional insights into grassland bird ecology and inform targeted conservation actions.

Responses to this article can be read online at: http://www.ace-eco.org/issues/responses.php/1515

\section{Acknowledgments:}

We are grateful for assistance and data collection by past and present staff members of the Crane Trust, especially Tim Smith, Kelsey King, and Brice Krohn. We thank our collaborators at the USGS Bird Banding Lab and the Institute for Bird Populations, including Peter Pyle, Rodney Siegel, Ron Taylor, and Danielle Kaschube. Funding for field data collection, analysis, and publication was provided by the Crane Trust. We thank two anonymous reviewers and the editor Ryan Norris for helpful comments that allowed us to improve earlier versions of this manuscript, and Sylvain Gatti for correcting the French version of the abstract.

\section{LITERATURE CITED}

Ahlering, M. A. and C. L. Merkord. 2016. Cattle grazing and grassland birds in the northern tallgrass prairie. Journal of Wildlife Management 80(4):643-654. https://doi.org/10.1002/ jwmg.1049

Akaike, H. 1973. Information theory and an extension of the maximum likelihood principle. Pages 267-281 in B. N. Petrov and
F. Caski, editors. Proceedings of the Second International Symposium on Information Theory. Akademiai Kiado, Budapest, Hungary.

Anderson, R. C. 2006. Evolution and origin of the central grassland of North America: climate, fire, and mammalian grazers. Journal of the Torrey Botanical Society 133(4):626-647. https://doi.org/10.3159/1095-5674(2006)133[626:EAOOTC]2.0.CO;2

Anthony, T., D. E. Gill, D. M. Small, J. Parks, and H. F. Sears. 2013. Post-fledging dispersal of Grasshopper Sparrows (Ammodramus savannarum) on a restored grassland in Maryland. Wilson Journal of Ornithology 125(2):307-313. https://doi. org/10.1676/12-121.1

Archibald, S. 2008. African grazing lawns-how fire, rainfall, and grazer numbers interact to affect grass community states. Journal of Wildlife Management 72:492-501. https://doi.org/10.2193/2007-045

Augustine, D. J., and D. G. Milchunas. 2009. Vegetation responses to prescribed burning of grazed shortgrass steppe. Rangeland Ecology and Management 62(1):89-97. https://doi.org/10.2111/08-135

Balent, K. L., and C. J. Norment. 2003. Demographic characteristics of a Grasshopper Sparrow population in a highly fragmented landscape of western New York state. Journal of Field Ornithology 74(4):341-348. https://doi.org/10.1648/0273-8570-74.4.341

Barbour, M. H., J. H Burk, and W. D. Pitts. 1980. Terrestrial plant ecology. Benjamin Cummings, Menlow Park, California, USA.

Bartoń, K. 2019. MuMIn: Multi-Model inference. R package version 1.43.15. [online] URL: https://CRAN.R-project.org/ package $=$ MuMIn

Briggs, J. M., and A. K. Knapp. 1995. Interannual variability in primary production in tallgrass prairie: climate, soil moisture, topographic position, and fire as determinants of aboveground biomass. American Journal of Botany 82:1024-1030. https://doi. org/10.1002/j.1537-2197.1995.tb11567.x

Briggs, J. M., A. K. Knapp, J. M. Blair, J. L. Heisler, G. A. Hoch, M. S. Lett, and J. K. McCarron. 2005. An ecosystem in transition: causes and consequences of the conversion of mesic grassland to shrubland. BioScience 55(3):243-254. https://doi.org/10.1641/0006-3568 (2005)055[0243:AEITCA]2.0.CO;2

Bring, J. 1994. How to standardize regression coefficients. American Statistician 48(3):209-213. https://doi.org/10.2307/2684719

Brooks, M. E., K. Kristensen, K. J. van Benthem, A. Mangusson, C. W. Berg, A. Nielsen, H. J. Skaug, M. Maechler, and B. M. Bolker. 2017. glmmTMB balances speed and flexibility among packages for zero-inflated generalized linear mixed modeling. $R$ Journal 9(2):378-400. https://doi.org/10.32614/RJ-2017-066

Burnham, K. P., and D. R. Anderson. 2002. Model selection and multimodel inference: a practical information-theoretic approach. Second edition. Springer-Verlag, New York, New York, USA.

Butchart, S. H. M., M. Walpole, B. Collen, A. van Strien, J. P. W. Scharlemann, R. E. A. Almond, J. E. M. Baillie, B. Bomhard, C. Brown, J. Bruno, et al. 2010. Global biodiversity: indicators of recent declines. Science 328:1164-1168. https://doi.org/10.1126/ science. 1187512 
Carroll, J. M., C. A. Davis, R. D. Elmore, and S. D. Fuhlendorf. 2015. A ground-nesting galliform's response to thermal heterogeneity: implications for ground-dwelling birds. PLoS ONE 10:e0143676. https://doi.org/10.1371/journal.pone.0143676

Collins, S. L. 1990. Introduction: fire as a natural disturbance in tallgrass prairie ecosystems. Pages 3-7 in S. L. Collins and L. L. Wallace, editors. Fire in North American tallgrass prairies. University of Oklahoma Press, Norman, Oklahoma.

Collins, S. L. 2000. Disturbance frequency and community stability in native tallgrass prairie. American Naturalist 155 (3):311-325. https://doi.org/10.1086/303326

Coppedge, B. R., D. M. Engle, C. S. Toepfer, and J. H. Shaw. 1998. Effects of seasonal fire, bison grazing and climatic variation on tallgrass prairie vegetation. Plant Ecology 139(2):235-246. https:// doi.org/10.1023/a:1009728104508

Coppedge, B. R., S. D. Fuhlendorf, W. C. Harrell, and D. M. Engle. 2008. Avian community responses to vegetation and structural features in grasslands managed with fire and grazing. Biological Conservation 141:1196-1203. https://doi.org/10.1016/j. biocon.2008.02.015

Currier, P. J. 1982. The floodplain vegetation of the Platte River: phytosociology, forest development, and seedling establishment. Dissertation. Iowa State University, Ames, Iowa, USA. https:// doi.org/10.31274/rtd-180813-7949

Dechant, J. A., M. F. Dinkins, D. H. Johnson, L. D. Igl, C. M. Goldade, B. D. Parkin, and B. R. Euliss. 2002. Effects of management practices on grassland birds: Upland Sandpiper. U.S. Geological Survey Northern Prairie Wildlife Research Center, Jamestown, North Dakota, USA.

Delaney, M. F., S. B. Linda, B. Pranty, and D. W. Perkins. 2002. Density and reproductive success of Florida grasshopper sparrows following fire. Journal of Range Management 55 (4):336-340. https://doi.org/10.2458/azu_jrm_v55i4_delany

Delaney, M. F., H. M. Stevenson, and R. McCracken. 1985. Distribution, abundance, and habitat of Florida Grasshopper Sparrow. Journal of Wildlife Management 41:626-631. https://doi. org/10.2307/3801684

Derner, J. D., and R. H. Hart. 2007. Grazing-induced modifications to peak standing crop in northern mixed-grass prairie. Rangeland Ecology and Management 60(3):270-276. https://doi.org/10.2111/1551-5028(2007)60[270:GMTPSC]2.0.CO;2

DeSante, D. F., K. M. Burton, O. Velez, D. Froelich, D. Kaschube, and S. Albert. 2017. MAPS Manual 2017 Protocol. Institute for Bird Populations, Point Reyes Station, California, USA. [online] URL: http://www.birdpop.org/pages/maps.php

DeSante, D. F., and D. R. Kaschube. 2009. The monitoring avian productivity and survivorship (MAPS) program 2004, 2005, and 2006 report. Bird Populations 9:86-169.

Elliott, L. H., and D. H. Johnson. 2018. The Grasshopper Sparrow as an indicator species in tallgrass prairies. Journal of Wildlife Management 82(5):1074-1081. https://doi.org/10.1002/ jwmg. 21447
Flanagan, L. B., and B. G. Johnson. 2005. Interacting effects of temperature, soil moisture, and plant biomass production on ecosystem respiration in a northern temperate grassland. Agricultural and Forest Meteorology 130(3-4):237-253. https:// doi.org/10.1016/j.agrformet.2005.04.002

Flanagan, L. B., E. J. Sharp, and M. G. Letts. 2013. Response of plant biomass and soil respiration to experimental warming and precipitation manipulation in a Northern Great Plains grassland. Agricultural and Forest Meteorology 173:40-52. https://doi. org/10.1016/j.agrformet.2013.01.002

Fletcher, Jr., R. J., and R. R. Koford. 2002. Habitat and landscape associations of breeding birds in native and restored grasslands. Journal of Wildlife Management 66(4):1011-1022. https://doi. org/10.2307/3802933

Foden, W. B., S. H. M. Butchart, S. N. Stuart, J. C. Vié, H. R. Akçakaya, A. Angulo, L. M. DeVantier, A. Gutsche, E. Turak, L. Cao, S. D. Donner, V. Katariya, R. Bernard, R. A. Holland, A. F. Hughes, S. E. O'Hanlon, S. T. Garnett, C. H. Şekercioğlu, and G. M. Mace. 2013. Identifying the world's most climate change vulnerable species: a systematic trait-based Assessment of all birds, amphibians and corals. PLoS ONE 8(6):e65427. https:// doi.org/10.1371/journal.pone.0065427

Fogarty, D. T., R. D. Elmore, S. D. Fuhlendorf, and S. R. Loss. 2017. Influence of olfactory and visual cover on nest site selection and nest success for grassland-nesting birds. Ecology and Evolution 7(16):6247-6258. https://doi.org/10.1002/ece3.3195

Foster, K. R., C. M. Godwin, P. Pyle, and J. F. Saracco. 2017. Reclamation and habitat-disturbance effects on land bird abundance and productivity indices in the oil sands region of northeastern Alberta, Canada. Restoration Ecology 25 (4):532-538. https://doi.org/10.1111/rec.12478

Fuhlendorf, S. D., and D. M. Engle. 2004. Application of the firegrazing interaction to restore a shifting mosaic on tallgrass prairie. Journal of Applied Ecology 41(4):604-614. https://doi. org/10.1111/j.0021-8901.2004.00937.x

Fuhlendorf, S. D., D. M. Engle, J. Kerby, and R. G. Hamilton. 2009. Pyric herbivory: rewilding landscapes through the recoupling of fire and grazing. Conservation Biology 23:588-598. https://doi.org/10.1111/j.1523-1739.2008.01139.x

Fuhlendorf, S. D., W. C. Harrell, D. M. Engle, R. G. Hamilton, C. A. Davis, and D. M. Leslie, Jr. 2006. Should heterogeneity be the basis for conservation? Grassland bird response to fire and grazing. Ecological Applications 16(5):1706-1716. https://doi. org/10.1890/1051-0761(2006)016[1706:SHBTBF]2.0.CO;2

George, T. L., A. C. Fowler, R. L. Knight, and L. C. McEwen. 1992. Impacts of a severe drought on grassland birds in western North Dakota. Ecological Applications 2:275-284. https://doi. org/10.2307/1941861

Gibson, D. J., and L. C. Hulbert. 1987. Effects of fire, topography, and year-to-year climatic variation on species composition in tallgrass prairie. Vegetation 72:175-185.

Gorzo, J. M., A. M. Pidgeon, W. E. Thogmartin, A. J. Allstadt, V. C. Radeloff, P. J. Heglund, and S. J. Vavrus. 2016. Using the 
North American Breeding Bird Survey to assess broad-scale response of the continent's most imperiled avian community, grassland birds, to weather variability. Condor 118(3):502-512. https://doi.org/10.1650/CONDOR-15-180.1

Guiliano, W. M., and S. E. Daves. 2002. Avian response to warmseason grass use in pasture and hayfield management. Biological Conservation 106:1-9. https://doi.org/10.1016/S0006-3207(01) 00126-4

Hamilton, R. G. 2007. Restoring heterogeneity on the Tallgrass Prairie Preserve: applying the fire-grazing interaction model. Pages 163-169 in R. E. Masters and K. E. M. Galley, editors. Proceedings of the 23rd Tall Timbers Fire Ecology Conference: Fire in Grassland and Shrubland Ecosystems. Tall Timbers Research Station, Tallahassee, Florida, USA.

Herkert, J. R. 1998 (revised 2002). Effects of management practices on grassland birds: Henslow's Sparrow. U.S. Geological Survey, Northern Prairie Wildlife Research Center, Jamestown, North Dakota, USA. https://doi.org/10.3133/70159918

Hovick, T. J., J. R. Miller, S. J. Dinsmore, D. M. Engle, D. M. Debinski, and S. D. Fuhlendorf. 2012. Effects of fire and grazing on Grasshopper Sparrow nest survival. Journal of Wildlife Management 76(1):19-27. https://doi.org/10.1002/jwmg.243

Hurvich, C. M., and C. Tsai. 1989. Regression and time series model selection in small samples. Biometrika 76(2):297-307. https://doi.org/10.1093/biomet/76.2.297

Johnsgard, P. A., and M. B. Brown. 2013. Birds of the Central Platte River Valley and adjacent counties. Zea E-Books, No. 15. University of Nebraska-Lincoln Libraries, Lincoln, Nebraska, USA.

Johnson, T. N., P. L. Kennedy, T. DelCurto, and R. V. Taylor. 2011. Bird community responses to cattle stocking rates in a Pacific Northwest bunchgrass prairie. Agriculture, Ecosystems \& Environment 144(1):338-346. https://doi.org/10.1016/j.agee.2011.10.003

Jonas, J. L., and A. Joern. 2007. Grasshopper (Orthoptera: Acrididae) communities respond to fire, bison grazing and weather in North American tallgrass prairie: a long-term study. Oecologia 153(3):699-711. https://doi.org/10.1007/s00442-007-0761-8

Jones, S. L., J. S. Dieni, M. T. Green, and P. J. Gouse. 2007. Annual return rates of breeding grassland songbirds. Wilson Journal of Ornithology 119(1):89-94. https://doi.org/10.1676/05-158.1

Junk, W. J., P. B. Bayley, and R. E. Sparks. 1989. The flood pulse concept in river-floodplain systems. Canadian Special Publication of Fisheries and Aquatic Sciences 106:11.

Kaul, R. B., and S. B. Rolfsmeier. 1993. Native vegetation of Nebraska (Scale 1:1,000,000). Conservation and Survey Division, University of Nebraska- Lincoln, Lincoln, Nebraska, USA.

Kaul, R. B., D. Sutherland, and S. Rolfsmeier. 2006. The flora of Nebraska. School of Natural Resources, University of NebraskaLincoln, Lincoln, Nebraska, USA.

Kim, D. H. 2005. First Nebraska nest record for Henslow's Sparrow. Prairie Naturalist 37:171-173.
Kim, D. H., W. E. Newton, G. R. Lingle, and F. Chavez-Ramirez. 2008. Influence of grazing and available moisture on breeding densities of grassland birds in the Central Platte River Valley, Nebraska. Wilson Journal of Ornithology 120(4):820-829. https:// doi.org/10.1676/07-153.1

Krapu, G. L., D. A. Brandt, P. J. Kinzel, and A. T. Pearse. 2014. Spring migration ecology of the mid-continent Sandhill Crane population with an emphasis on use of the Central Platte River Valley, Nebraska. Wildlife Monographs 189(1):1-41. https://doi. org/10.1002/wmon.1013

La Sorte, F., D. Fink, and A. Johnson. 2019. Time of emergence of novel climates for North American migratory bird populations. Ecography 42(6):1079-1091. https://doi.org/10.1111/ecog.04408

Langham, G. M., J. G. Schuetz, T. Distler, C. U. Soykan, and C. Wilsey. 2015. Conservation status of North American birds in the face of future climate change. PLOS ONE 10(9):e0135350. https:// doi.org/10.1371/journal.pone.0135350

Lingle, G. R., and M. A. Hay. 1982. A checklist of the birds of Mormon Island Crane Meadows. Nebraska Bird Review 50:27-36.

Martin, A. C., H. S. Zim, and A. L. Nelson. 1951. American wildlife and plants: a guide to wildlife food habits: the use of trees, shrubs, weeds, and herbs by birds and mammals of the United States. Dover, New York, New York, USA.

Millennium Ecosystem Assessment. 2005. Ecosystems and human well-being: synthesis. Island, Washington, D.C., USA.

National Oceanic and Atmospheric Administration (NOAA). 2017. NOAA National Centers for Environmental Information: climate at a glance: city time series. NOAA, Washington, D.C., USA. [online] URL: https://www.ncdc.noaa.gov/cag/

North American Bird Conservation Initiative (NABCI). 2017. Bird conservation regions map. NABCI, Washington, D.C., USA. [online] URL: http://nabci-us.org/resources/bird-conservationregions-map

O'Hara, R. B., and D. J. Kotze. 2010. Do not log-transform count data. Ecology and Evolution 1(2):118-122.

Ojima, D., J. Steiner, S. McNeeley, A. Childress, and K. Cozetto. 2012. Great Plains climate assessment technical report. National Climate Assessment, Washington, D.C., USA.

Patterson, M. P., and L. B. Best. 1996. Bird abundance and nesting success in Iowa CRP fields: the importance of vegetation structure and composition. American Midland Naturalist 135 (1):153-167. https://doi.org/10.2307/2426881

Poague, K. 2019. Important bird areas: Nebraska. National Audubon Society, New York, New York, USA. [online] URL: https://www.audubon.org/important-bird-areas/state/nebraska

Powell, A. F. L. A. 2006. Effects of prescribed burns and bison (Bos bison) grazing on breeding bird abundances in tallgrass prairie. Auk 123(1):183-197. https://doi.org/10.1093/auk/123.1.183

Powell, A. F. L. A. 2008. Responses of breeding birds in tallgrass prairie to fire and cattle grazing. Journal of Field Ornithology 79 (1):41-52. https://doi.org/10.1111/j.1557-9263.2008.00144.x 
Pyle, P. 1997. Identification guide to North American Birds. Slate Creek Press, Bolinas, California, USA.

R Core Team. 2017. R: A language and environment for statistical computing. R Foundation for Statistical Computing, Vienna, Austria.

Rahmig, C. J., W. E. Jensen, and K. A. With. 2009. Grassland bird responses to land management in the largest remaining tallgrass prairie. Conservation Biology 23(2):420-432. https://doi. org/10.1111/j.1523-1739.2008.01118.x

Reinking, D. L. 2005. Fire regimes and avian responses in the central tallgrass prairie. Studies in Avian Biology 30:116-126.

Rickletts, T. H., E. Dinerstein, K. M. Carney, R. Abell, and S. Walters. 1999. Terrestrial ecoregions of North America. Island, Washington, D.C., USA.

Ripple, W. J., C. Wolf, T. M. Newsome, M. Galetti, M. Alamgir, E. Crist, M. I. Mahmoud, and W. F. Laurance. 2017. World scientists' warning to humanity: a second notice. Bioscience 67 (12):1026-1028. https://doi.org/10.1093/biosci/bix125

Roberts, A. J., C. W. Boal, and H. A. Whitlaw. 2017. Nesting ecology of grassland birds following a wildfire in the southern Great Plains. Southwestern Naturalist 62(1):39-45. https://doi. org/10.1894/0038-4909-62.1.39

Rosenberg, K. V., A. M. Dokter, P. J. Blancher, J. R. Sauer, A. C. Smith, P. A. Smith, J. C. Stanton, A. Panjabi, L. Helft, M. Parr, and P. P. Marra. 2019. Decline of the North American avifauna. Science 366(6461):120-124. https://doi.org/10.1126/science.aaw1313

Rosenberg, K. V., J. A. Kennedy, R. Dettmers, R. P. Ford, D. Reynolds, J. D. Alexander, C. J. Beardmore, P. J. Blancher, R. E. Bogart, G. S. Butcher, A. F. Camfield, A. Couturier, et al. 2016. Partners in Flight Landbird Conservation Plan: 2016 revision for Canada and continental United States. Partners in Flight Science Committee.

Ruth, J. M. 2015. Status assessment and conservation plan for the Grasshopper Sparrow (Ammodramus savannarum). Version 1.0. U.S. Fish and Wildlife Service, Lakewood, Colorado, USA.

Samson, F. B., F. L Knopf, and W. R. Ostlie. 2004. Great Plains ecosystems: past, present, and future. Wildlife Society Bulletin 32 (1):6-15. https://doi.org/10.2193/0091-7648(2004)32[6:GPEPPA] 2.0. $\mathrm{CO} ; 2$

Saracco, J. F., R. B. Siegel, L. Helton, S. L. Stock, and D. F. DeSante. 2019. Phenology and productivity in a montane bird assemblage: trends and responses to elevation and climate variation. Global Change Biology 25(3):985-996. https://doi. org/10.1111/gcb.14538

Sauer J. R., J. E. Hines, J. E. Fallon, and K. L. Pardieck. 2014. The North American Breeding Bird Survey, results and analysis 1966-2013. Version 01.30.2015. U.S. Geological Survey Patuxent Wildlife Resource Center, Laurel, Maryland, USA.

Schlaepfer M. A., M. C. Runge, and P. W. Sherman. 2002. Ecological and evolutionary traps. Trends in Ecology \& Evolution 17:474-480. https://doi.org/10.1016/S0169-5347(02)02580-6
Sharpe, R. S., W. R. Silcock, and J. G. Jorgensen. 2001. Birds of Nebraska: their distribution \& temporal occurrence. University of Nebraska Press, Lincoln, Nebraska, USA.

Silcock, W. R., and J. G. Jorgensen. 2018. Grasshopper Sparrow (Ammodramus savannarum), Version 1.0. In Birds of NebraskaOnline. https://birds.outdoornebraska.gov/grasshopper-sparrow/

Sohl, T., J. Dornbierer, and S. Wika. 2019. Linking landscapes and people - projecting the future of the Great Plains. Rangelands 41(2):79-87. https://doi.org/10.1016/j.rala.2018.12.001

Sutter, B., and G. Ritchison. 2005. Effects of grazing on vegetation structure, prey availability, and reproductive success of Grasshopper Sparrows. Journal of Field Ornithology 76:345-351. https://doi.org/10.1648/0273-8570-76.4.345

Swengel, S. R., and A. B. Swengel. 2001. Relative effects of litter and management on grassland bird abundance in Missouri, USA. Bird Conservation International 11:113-128. https://doi. org/10.1017/S095927090100020X

Teague, W. R., S. L. Dowhower, and J. A. Waggoner. 2004. Drought and grazing patch dynamics under different grazing management. Journal of Arid Environments 58(1):97-117. https:// doi.org/10.1016/S0140-1963(03)00122-8

Thogmartin, W. E., M. G. Knutson, and J. R. Sauer. 2006. Predicting regional abundance of rare grassland birds with a hierarchical spatial count model. Condor 108(1):25-46. https:// doi.org/10.1093/condor/108.1.25

Touma, D., M. Ashfaq, M. Nayak, S. C. Kao, and N. Diffenbaugh. 2015. A multi-model and multi-index evaluation of drought characteristics in the $21^{\text {st }}$ century. Journal of Hydrology 526:196-207. https://doi.org/10.1016/j.jhydrol.2014.12.011

Van Horne, B. 1983. Density as a misleading indicator of habitat quality. Journal of Wildlife Management 47(4):893-901. https:// doi.org/10.2307/3808148

Vickery, P. D. 1996. Grasshopper Sparrow (Ammodramus savannarum), version 2.0. In A. F. Poole and F. B. Gill, editors. The birds of North America. Cornell Lab of Ornithology, Ithaca, New York, USA. https://doi.org/10.2173/bna.239

Vickery, P. D., P. L. Tubaro, J. M. C. Silva, B. G. Peterjohn, J. R. Herkert, and R. B. Cavalcanti. 1999. Conservation of grassland birds in the Western Hemisphere. Studies in Avian Biology 19:2-26.

Williams, G. P. 1978. The case of the shrinking channels: the North Platte and Platte Rivers in Nebraska. Circulars of the United States Geological Survey 781:48. https://doi.org/10.3133/ cir781

Willson, G. D., and J. Stubbendieck. 2000. A provisional model for smooth brome management in degraded tallgrass prairie. Ecological Restoration 18(1):34-38. https://doi.org/10.3368/ er. 18.1 .34

Winter, M., D. H. Johnson, and J. A. Shaffer. 2005. Variability in vegetation effects on density and nesting success of grassland birds. Journal of Wildlife Management 69(1):185-197. https://doi. org/10.2193/0022-541X(2005)069<0185:VIVEOD>2.0.CO;2 
Avian Conservation and Ecology 15(1): 4 http://www.ace-eco.org/vol15/iss1/art4/

Yarnell, R. W., D. M. Scott, C. T. Chimimba, and D. J. Metcalfe. 2007. Untangling the roles of fire, grazing and rainfall on small mammal communities in grassland ecosystems. Oecologia 154:387-402. https://doi.org/10.1007/s00442-007-0841-9

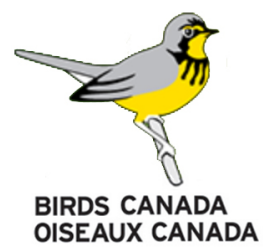

